\title{
Influence of Mikania laevigata Extract over the Genotoxicity Induced by Alkylating Agents
}

\author{
Daliane Medeiros Mazzorana, ${ }^{1}$ Vanessa Nicolau, ${ }^{2}$ Jeverson Moreira, ${ }^{2}$ \\ Patrícia de Aguiar Amaral, ${ }^{2}$ and Vanessa Moraes de Andrade ${ }^{1}$ \\ ${ }^{1}$ Laboratório de Biologia Celular e Molecular, Programa de Pós-Graduação em Ciências da Saúde, \\ Universidade do Extremo Sul Catarinense (UNESC), Avenida Universitária 1105, Bairro Universitário, \\ 88806-000 Criciúma, SC, Brazil \\ ${ }^{2}$ Grupo de Estudos Etnofarmacológicos Visando à Obtenção de Substâncias Bioativas, Universidade do Extremo Sul \\ Catarinense (UNESC), Avenida Universitária 1105, Bairro Universitário, 88806-000 Criciúma, SC, Brazil
}

Correspondence should be addressed to Vanessa Moraes de Andrade; vmoraesdeandrade@yahoo.com.br

Received 29 December 2012; Accepted 23 January 2013

Academic Editors: F. Ducancel, H. Pan-Hou, and F.-Y. Yu

Copyright (C) 2013 Daliane Medeiros Mazzorana et al. This is an open access article distributed under the Creative Commons Attribution License, which permits unrestricted use, distribution, and reproduction in any medium, provided the original work is properly cited.

\begin{abstract}
Medicinal plants are still widely used worldwide; yet for some species, little or no information is available concerning their biological activity, specially their genotoxic and antimutagenic potential. Mikania laevigata (Asteraceae) is a native plant from South America, and its extracts are largely used to treat respiratory complaints. The aim of the present work was then to evaluate, in vivo, the potential biological activity of M. laevigata on the genotoxicity induced by methyl methanesulfonate (MMS) and cyclophosphamide (CP), using the comet assay. Male CF1 mice were divided into groups of 5-6 animals, received by gavage $0.1 \mathrm{~mL} / 10 \mathrm{~g}$ body wt of water, Mikania laevigata extract (MLE), MMS, and CP. Results showed that treatment with $200 \mathrm{mg} / \mathrm{kg}$ of the MLE previously to MMS and $\mathrm{CP}$ administration, respectively, reduced the damage index (DI) in 52\% and 60\%, when compared to DI at 24 h. Pretreatment also reduced the damage frequency (DF) in 56\% (MMS) and 58\% (CP), compared to DF at $24 \mathrm{~h}$. MLE administration has been shown to protect mouse DNA from damage induced by alkylating agents; this corroborates to the biological activities of M. laevigata and points towards the need of plant compounds isolation to proceed with further studies.
\end{abstract}

\section{Introduction}

The diversity of plant species in Brazil is a potential source of biologically active compounds. The use of medicinal plants is a generalized practice in folk medicine for the treatment of different types of diseases [1-4], and they are promising sources for the discovery of novel potentially therapeutic agents [5]. However, in the majority of cases, there is no proof of the efficacy of treatment popular use, nor there has been an adequate evaluation of medicinal plants for possible adverse effects [6].

Among various medicinal plants used in Brazil stands out Mikania genus plant (Asteraceae family), a subscrub creeper of woody branches, known popularly as "guaco" [7]. The genus Mikania includes around 450 species, many of which are found in Brazil and other South American countries, besides tropical regions of Asia and Africa [8]. Although the species considered in the Farmacopeia Brasileira is the Mikania glomerata (in the use of syrup), the Mikania laevigata is the common one commercialized due to similarities to both internal and external morphology, majority of chemical substances (coumarin), and the same habitat [9].

Mikania laevigata has been widely used as infusions or plasters, while the crude extract of this species is commonly commercialized as phytomedicine, mainly to treat inflammatory disorders, such as bronchitis, chronic lung diseases, and bronchial asthma [10]. Among other effects that have been described to the Mikania laevigata are anti-inflammatory, antioedematogenic [11], antiulcerogenic [12], antimicrobial $[13,14]$, antispasmodic, and bronchodilatory [15]. 
Previous studies have described the presence of various chemical constituents of Mikania laevigata, including coumarin, kaurenoic acid, stigmasterol, cinamoil grandiflorus acid, and dihydrocoumarin [16]. Coumarin is a major chemical substance found in Mikania laevigata, and there is a relationship between it and the pharmacological action of this plant. For this reason, it has been used as a chemical marker in pharmaceutical presentations $[17,18]$. Furthermore, studies have pointed coumarin as a potential substance for the treatment of cancer [19], with growth inhibition activity and cell kill in various tumor cells lines [20], and a liver toxicant and not showing toxicity in the reproductive system in male Wistar rats [21].

Many studies have been developed to demonstrate the actions of Mikania, expanding further our knowledge about this plant. Suyenaga et al. [11] have developed a study with Mikania laevigata, in which results indicated that this plant was more effective in producing the anti-inflammatory activity than Mikania glomerata. There is little information in the literature on the action of Mikania laevigata in genetic level, but Simmons and Snustad [22], using Mikania glomerata, reported that infusion of this species could cause damage that was not reversible by the cell's DNA repair system. Costa et al. [23] also noted an increase in genotoxicity, using infusion of Mikania glomerata in highest doses.

While there is widespread use of medicinal plants in popular medicine for the treatment of different diseases, not all species are harmless to human health and may present toxic and mutagenic substances in their phytochemical composition [4]. On the other hand, a protective action of phytochemical compounds on genetic material has been reported, leading to its repair or to preserving its integrity [24]. Considering that there are few data on the biological effects of the extracts of Mikania laevigata, mainly in genetic level, this work aims to evaluate, in vivo, the effect of $M$. laevigata on the genotoxicity of the alkylating agents Methyl methanesulfonate (MMS), a direct acting mutagen, and cyclophosphamide $(\mathrm{CP})$, that requires metabolism to become active, using the comet assay.

\section{Materials and Methods}

2.1. Identification and Extraction of Plant Material. Aerial parts (leaves) of M. laevigata, family Asteraceae, were collected in Grão Pará, SC, Brazil in September 2008.

A voucher specimen (no. CRI 7379) of M. laevigata was deposited at Herbarium Pe. Dr. Raulino Reitz, Universidade do Extremo Sul Catarinense, Criciúma, SC, Brazil. The leaves were allowed to dry under air circulation $\left(40^{\circ} \mathrm{C}\right)$ for 3 days and were powdered. The resulting powder $(400 \mathrm{~g})$ was subjected to dynamic maceration with $2 \mathrm{~L}$ of ethanol: water $(70: 30, \mathrm{vol} / \mathrm{vol})$ solution for 3 hours. The extract was filtered, and this procedure was repeated twice. The solvent was evaporated in a rotary evaporator, and the residue was dissolved in distilled water [14, 25].

2.2. Phytochemical Screening. The phytochemical analysis (flavonoids, tannins, anthraquinones, alkaloids, saponins, coumarins, and cardiac glycosides) of the aerial parts of
M. laevigata was carried out according to the methods described by Harborne [26]. The thin layer chromatography analyses were performed following systems and developers indicated by Wagner and Bladt [27], and aluminum chloride colorimetric method was used for flavonoids quantitative determination [28]. Each plant extracts $(0.5 \mathrm{~mL}$ of $1: 10 \mathrm{~g})$ in methanol were separately mixed with $1.5 \mathrm{~mL}$ of methanol, $0.5 \mathrm{~mL}$ of $2 \%$ aluminum chloride, $0.1 \mathrm{~mL}$ of $1 \mathrm{M}$ potassium acetate, and $2.8 \mathrm{~mL}$ of distilled water. It remained at room temperature for $30 \mathrm{~min}$; the absorbance of the reaction mixture was measured at $425 \mathrm{~nm}$ with Biospectro Model SP$22 \mathrm{UV} /$ Visible spectrophotometer.

2.3. Animals. Male CF1 mice between 6-8 weeks and weighing between 30 and $50 \mathrm{~g}$ were obtained from the Central Animal House of the Universidade do Extremo Sul Catarinense and caged in groups of five with six animals each, provided with commercial mice chow and water ad libitum, and maintained on a 12-hour light: 12-hour dark cycle. All studies were performed in accordance with National Institutes of Health guidelines and with the approval of the Ethics Committee of the Universidade do Extremo Sul Catarinense.

2.4. Treatments and Test Substances. The treatment groups received by gavage $0.1 \mathrm{~mL} / 10 \mathrm{~g}$ body wt of (a) water, (b) Mikania laevigata extract (MLE), (c) MMS, and (d) CP (Table 1). Dose levels of MMS were $40 \mathrm{mg} / \mathrm{kg}$ body/wt and $25 \mathrm{mg} / \mathrm{kg}$ body/wt for CP. All substances were prepared just before treatment and protected from light.

2.5. Blood Sample Collection. One or two drops of blood were collected from mouse tail tips by means of a small incision [29]. Animals were sampled 24 and/or $48 \mathrm{~h}$ after treatment (Table 1). Drug administration and blood sampling were performed as described previously [30]. Peripheral white blood cells are among the most used cells for genotoxicity studies, mainly with the comet assay. They circulate through the entire body and are easily obtained.

2.6. Comet Assay. The alkaline comet assay was performed as described by Singh et al. [31] with adaptations by da Silva et al. [32]. Blood samples were drawn from the caudal vein of each mice and mixed with the anticoagulant heparin.

Cells isolated from tissues $(5-10 \mu \mathrm{L})$ were embedded in a layer consisting of $95 \mu \mathrm{L}$ of $0.75 \%$ low melting point agarose gel on frosted slides and immersed in a lysis buffer (2.5 M NaCl, $100 \mathrm{mM}$ EDTA, and $10 \mathrm{mM}$ Tris [pH 10.010.5] with freshly added $1 \%$ Triton X-100 and $10 \%$ dimethyl sulfoxide) for a minimum of 1 hour and a maximum of 1 week. Subsequently, the slides were incubated in freshly made alkaline buffer $(300 \mathrm{mM} \mathrm{NaOH}$ and $1 \mathrm{mM}$ EDTA, $\mathrm{pH}>$ 13) for 20 minutes. The nuclei were electrophoresed for 20 minutes at $25 \mathrm{~V}(0.90 \mathrm{~V} / \mathrm{cm})$ and $300 \mathrm{~mA}$, and then the alkali was neutralized with $0.4 \mathrm{M}$ Tris $(\mathrm{pH} 7.5)$. After the neutralization, the slides were fixed $(15 \% \mathrm{w} / \mathrm{v}$ trichloroacetic acid, $5 \% \mathrm{w} / \mathrm{v}$ zinc sulfate, and $5 \%$ glycerol), washed in distilled water, and overnight dried. The gels were rehydrated for $5 \mathrm{~min}$ in distilled water and then stained for $15 \mathrm{~min}\left(37^{\circ} \mathrm{C}\right)$ with a solution containing the following sequence: $34 \mathrm{~mL}$ of 
TABLE 1: Experimental procedures.

\begin{tabular}{|c|c|c|c|}
\hline \multirow{2}{*}{ Procedure } & \multicolumn{3}{|c|}{ Exposure schedule } \\
\hline & $0 \mathrm{~h}$ & $24 \mathrm{~h}$ & $48 \mathrm{~h}$ \\
\hline \multirow{4}{*}{ Control } & \multirow{2}{*}{ 1st water treatment } & 1st blood sampling & \multirow{3}{*}{ 2nd blood sampling } \\
\hline & & 2nd water treatment & \\
\hline & \multirow{2}{*}{ 1st extracts treatment } & 1st blood sampling & \\
\hline & & 2nd extracts treatment & 2nd blood sampling \\
\hline \multirow{3}{*}{ Pretreatment } & \multirow{3}{*}{ 1st Treatment (extracts) } & 1st blood sampling & \\
\hline & & 2nd treatment: & 2nd blood sampling \\
\hline & & $\begin{array}{l}\text { (1) MMS } \\
\text { (2) CP }\end{array}$ & \\
\hline \multirow{2}{*}{ Posttreatment } & 1st treatment (agents) & 1st blood sampling & \\
\hline & $\begin{array}{l}\text { (1) MMS } \\
\text { (2) CP }\end{array}$ & 2nd treatment (Extracts) & 2nd blood sampling \\
\hline Alkylating agents & $\begin{array}{l}\text { Agentstreatment: } \\
\text { (1) MMS } \\
\text { (2) CP }\end{array}$ & 1st blood sampling & 2nd blood sampling \\
\hline
\end{tabular}

Solution B $(0.2 \% \mathrm{w} / \mathrm{v}$ ammonium nitrate, $0.2 \% \mathrm{w} / \mathrm{v}$ silver nitrate, $0.5 \% \mathrm{w} / \mathrm{v}$ tungstosilicic acid, $0.15 \% \mathrm{v} / \mathrm{v}$ formaldehyde, and $5 \% \mathrm{w} / \mathrm{v}$ sodium carbonate) and $66 \mathrm{~mL}$ of Solution A (5\% sodium carbonate). The staining was stopped with $1 \%$ acetic acid and the gels were air-dried [33].

2.7. Microscopic Analyses. Cells were scored from 0 (undamaged) to 4 (maximally damaged) according to the tail intensity (size and shape), resulting in a single DNA damage score (damage index) for each sample and, consequently, for each group (Figure 1). Thus, a damage index (DI) of the group could range from 0 (completely undamaged -100 cells $\times 0$ ) to 400 (maximum damage -100 cells $\times 4$ ) [34]. The percentage damage frequency (DF) was calculated for each sample on the basis of the number of cells with a tail versus with no tail.

2.8. Statistical Analysis. Student's $t$-test was used to compare DNA damage values between the different times ( $24 \mathrm{~h}$ versus $48 \mathrm{~h}, 24 \mathrm{~h}$ versus MLE pretreatment, and $48 \mathrm{~h}$ versus MLE posttreatment). Analysis of variance (ANOVA) was used to compare DNA damage induced by different substances at the same time ( 24 or $48 \mathrm{~h}$ ). A parametric ANOVA was used when data showed normal distribution and were homogeneous in variance. In this case, the Tukey post hoc test was applied for multiple comparisons. Statistical significance was considered at a level of $P<0.05$. All statistical analyses were performed independently for the two parameters evaluated. The statistical package used was BioEstat 5.0.

\section{Results}

After exposure of mice to water and MLE, little damage was seen in mouse peripheral blood cells sampled at $24 \mathrm{~h}$ through the comet assay (Table 2). There was no difference between these compounds for both the damage index as for the damage frequency. A slight increase in DNA damage

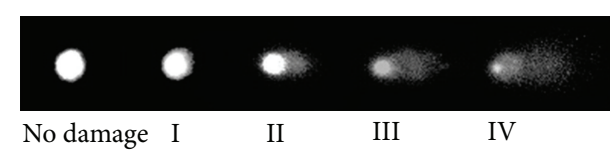

FIGURE 1: Comet assay. Evaluation of DNA damage using ethidium bromide (400x). The cells are assessed visually and received scores from 0 (undamaged) to 4 (maximally damaged), according to the size and shape of the tail.

was observed in these groups at $48 \mathrm{~h}$ of exposure, with significance for both groups compared to $24 \mathrm{~h}(P<0.001$, $t$-test); however the extent of DNA damage did not differ between mice treated with water and MLE (Table 2).

At $24 \mathrm{~h}$ of exposure, MMS and CP were genotoxic according to both parameters evaluated in comparison with water and MLE treatments ( $P<0.01$, ANOVA, Tukey) (Table 2). A reduction in DNA damage was observed for both MMS and $\mathrm{CP}$ at $48 \mathrm{~h}$, being significant in relation to $24 \mathrm{~h}$ in both groups $(P<0.001, t$-test $)$. Although decreasing in relation to $24 \mathrm{~h}$ values, the DNA damage levels for MMS and CP at $48 \mathrm{~h}$ remained significantly higher in relation to water and MLE (for DI and DF, $P<0.01$, ANOVA, Tukey) treatments (Table 2).

When the level of DNA damage in blood cells of mice treated with MMS and CP and sampled at $24 \mathrm{~h}$ was compared with mice pretreated with MLE, this compound was able to induce significant reduction in DNA damage caused by alkylating agents in both evaluated comet assay parameters $(P<0.001, t$-test) (Table 2$)$.

Posttreatment with MLE induced significant reduction in DNA damage in both parameters in blood cells for both mutagens in mice sampled at $48 \mathrm{~h}(P<0.001$, $t$-test $)$ (Table 2). 
TABLE 2: Detection of DNA damage by comet assay (DF and DI) in blood cells of mice exposed to water, Mikania laevigata extract (MLE), and/or cyclophosphamide (CP) or methyl methanesulfonate (MMS) and sampled at $24 \mathrm{~h}$ (with and without pretreatment with MLE) or $48 \mathrm{~h}$ (with and without posttreatment with MLE).

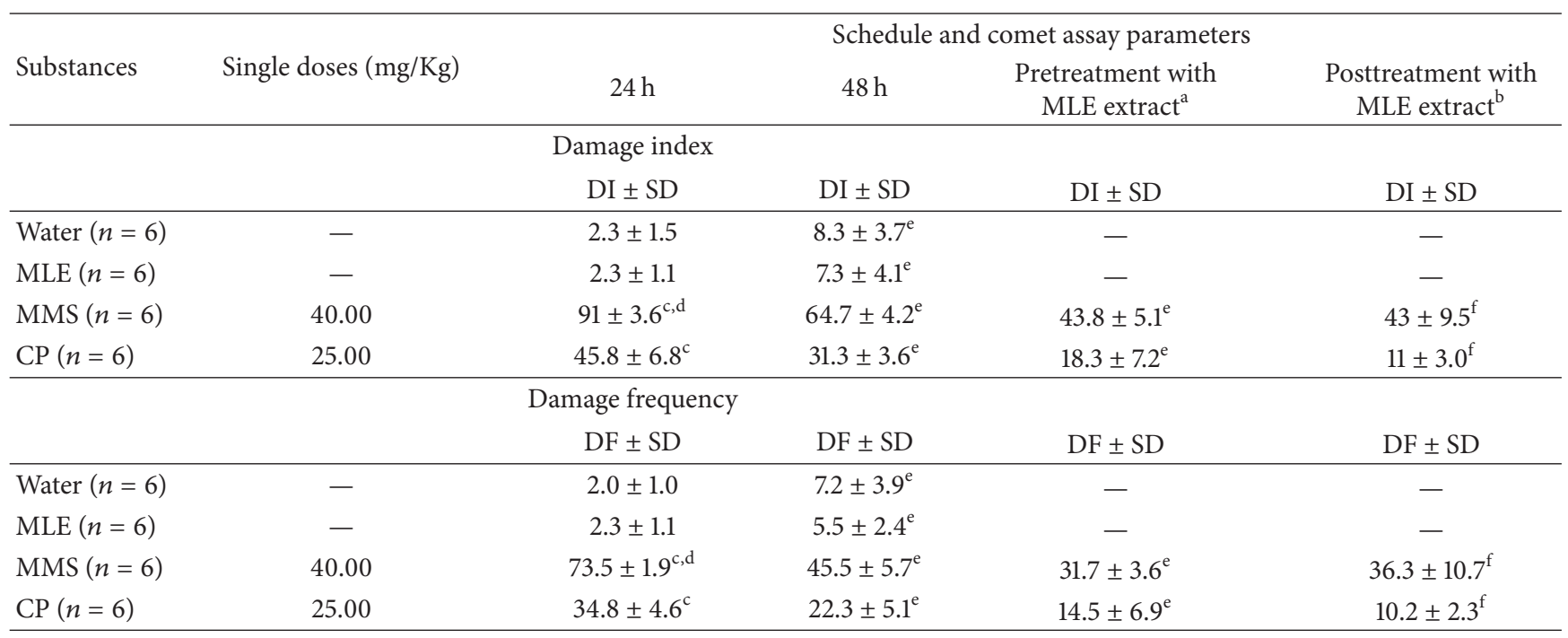

DI: damage index; DF: damage frequency; $n$ : number of individuals obtained from sum of independent experiments.

${ }^{\mathrm{a}}$ Group sampled $24 \mathrm{~h}$ after treatment with an alkylating agent.

${ }^{\mathrm{b}}$ Group sampled $48 \mathrm{~h}$ after treatment with an alkylating agent.

${ }^{c}$ Data significant in relation to water, EML in $24 \mathrm{~h}, P<0.01$ (ANOVA, Tukey).

${ }^{\mathrm{d}}$ Data significant in relation to group CP, $P<0.01$ (ANOVA, Tukey).

${ }^{\mathrm{e}}$ Data significant in relation to $24 \mathrm{~h}$ at, $P<0.001$ ( $t$-test).

${ }^{\mathrm{f}}$ Data significant in relation to $48 \mathrm{~h}$ at, $P<0.001$ ( $t$-test).

The phytochemical analyses of $M$. laevigata extract indicated the presence of coumarins, flavonoids, alkaloids, cardiac heterosides, and tannins. Other secondary metabolites such as anthraquinones and saponins were not detected.

\section{Discussion}

Medicinal plants and their derivatives have been used as an alternative to synthetic medicines in many countries. The major compound found in Mikania laevigata is coumarin, which has been described as being responsible for the pharmacological actions and as a chemical marker of this plant $[17,18]$.

Assessment of antigenotoxic potential of Mikania laevigata extract (MLE) is very important, whereas antimutagenic substances present in some plants have been shown to help in the prevention of cancer and other diseases [35-38].

In our experiments, low levels of DNA damage in blood cells of mice treated with different concentrations of extract and infusion of Mikania laevigata by the comet assay were detected. The damage index was similar to the groups treated with water and with a significant low value in relation to the groups treated with the mutagens MMS and CP that have demonstrated high levels of DNA damage. These results demonstrate that the Mikania laevigata is not genotoxic to cells and also proved the efficiency of the assay. In a previous study, there was also an evidence that the extract of this plant showed no signs of mutagenicity in the Salmonella/microsome assay (Ames assay) [39]. Additionally, da Silveira e Sá et al. [40] working with Wistar rats showed that administration of Mikania glomerata extract to these animals was not able to change any of the parameters studied, suggesting absence of mutagenic effect. However, although the studies of Fernandes and Vargas [39], da Silveira e Sá et al. [40], and ours have not demonstrated genotoxic activity of this plant, Martins and Santos [41], have reported that both Mikania glomerata and Mikania laevigata showed a toxic effect only following excessive consumption.

Oral administration of MLE in mice showed a reduction in the frequency and index rates of DNA damage induced by antineoplastic agents used in this study. With regard to cyclophosphamide (CP), the reduction was $60 \%$ and $65 \%$ for the DI in the groups pre- and posttreated, respectively. In relation to DF, the reduction was $58 \%$ and $54 \%$ in the groups pre- and posttreated, respectively.

With respect to DNA damage caused by the alkylant agent MMS, the reduction of the DI was 52\% and 33.5\% in the groups pre- and posttreated, respectively. In relation to $\mathrm{DF}$, the reduction was $57 \%$ and $20 \%$ in the groups preand posttreated, respectively. These results show that the hydroalcoholic extract of Mikania laevigata has a protective and reparative effect and could be considered not only in relation to its multiple pharmacological properties but also to reduce the genotoxicity of chemotherapeutic agents on normal cells.

Many authors attribute the anti-inflammatory and healing properties of MLE to the presence of coumarin, flavonoids, and tannins, and several studies have been carried 
out to verify this contribution [7, 42]. Our phytochemical screening of MLE showed the presence of flavonoids, phenolic compounds, tannins, coumarin, and alkaloids in accordance with the previous results.

The therapeutic use of plant containing flavonoids is vast, and many cases are still empirical. Although some results have shown that flavonoids may have a mutagenic effect, in general, these compounds are considered beneficial. Other research suggests that some flavonoids are responsible for antitumoral action. Used in the preventive chemotherapy of cancer, they showed the ability to interact on the genesis of cancer, blocking the stage of promotion, by inhibiting the synthesis of ornithine decarboxylase [43].

MMS can methylate nucleophilic regions of DNA and amino acid molecules, particularly at nitrogen atoms. MMS's genotoxicity is mediated by base modifications, which weaken the $\mathrm{N}$-glycosylic bond, leading to depurination/depyrimidination of DNA strands and the appearance of alkali-labile abasic sites (AP sites). The removal of AP sites by AP endonucleases cleaves DNA adjacent to these sites and generates DNA strand breaks in DNA [44, 45]. Pretreatment and posttreatment with MLE reduced MMS's genotoxicity about $52 \%$ and $33.5 \%$ in DI ( $57 \%$ and $20 \%$ in DF), respectively. Thus, MLE was both preventive and reparative for the damage caused by MMS. In pretreatment, phenolic compounds could have competed as target site for alkylation. With respect to posttreatment, both phenolic compounds could have influenced the kinetics of repair [46].

$\mathrm{CP}$ is absorbed well after oral administration. The parent compound is widely distributed throughout the body with a low degree of plasma protein binding (20\%). The half-life of $\mathrm{CP}$ is between 6 and 9 hours [47]. Once activated, CP can, besides monoadducts, also induce the formation of DNADNA and DNA-protein crosslinks [48]. CP has the ability to generate free radicals that cause endothelial and epithelial cell damage [47].

Pretreatment with MLE slightly reduced the level of DNA damage induced by CP $(60 \%$ and $58 \%$ reduction in DI and DF, resp.), while MLE posttreatment induced a significantly higher reduction in DNA damage $(65 \%$ and $54 \%$ reduction in DI and DF, resp.). Since CP requires metabolic activation before inducing DNA damage, it is likely that "guaco" components, such as phenolic compounds, alter the rate of metabolization and/or detoxification. In posttreatment, damage reduction was higher because both compounds could act as reactive species quenchers and DNA repair pathways modulators. Moreover, phenolics could have stimulated phase II enzymes and eliminated CP metabolites [29]. It is important to consider the kind of DNA damage generated by CP, particularly crosslinks. Such lesions can retard the migration of DNA fragments and lead to a wrong evaluation of the extent of DNA damage [48, 49].

4.1. Conclusions. In conclusion, consumption of MLE can be both protective and reparative of DNA damage induced in mouse blood cells by alkylating agents. Such protective effects of MLE differ depending on the mode of action of the mutagen. Our results demonstrate the ability of the in vivo comet assay to detect in vivo modulation of MMS and CP genotoxicity by MLE.

Further studies are recommended to determine the conditions for the use of this plant in vivo that would offer the benefits of their therapeutic properties without putting at risk the human health.

\section{Acknowledgment}

This research was supported by grants from Conselho Nacional de Desenvolvimento Científico e Tecnológico (CNPq).

\section{References}

[1] C. Beudot, M. P. de Méo, D. Dauzonne et al., "Evaluation of the mutagenicity and antimutagenicity of forty-two 3-substituted flavones in the Ames test," Mutation Research, vol. 417, no. 2-3, pp. 141-153, 1998.

[2] S. Bresolin and V. M. F. Vargas, "Mutagenic potencies of medicinal plants screened in the Ames test," Phytotherapy Research, vol. 7, no. 3, pp. 260-262, 1993.

[3] I. C. de Sá Ferreira and V. M. F. Vargas, "Mutagenicity of medicinal plant extracts in Salmonella/microsome assay," Phytotherapy Research, vol. 13, no. 5, pp. 397-400, 1999.

[4] V. M. F. Vargas, R. R. Guidobono, and J. A. P. Henriques, "Genotoxicity of plant extracts," Memórias do Instituto Oswaldo Cruz, vol. 86, supplement 2, pp. 67-70, 1991.

[5] G. M. Cragg, D. J. Newman, and K. M. Snader, "Natural products in drug discovery and development," Journal of Natural Products, vol. 60, no. 1, pp. 52-60, 1997.

[6] R. D. da Silveira e Sa, M. N. Leite, M. D. Reporedo, and R. N. de Almeida, "Evaluation of long-term exposure to Mikania glomerata (Sprengel) extract on male Wistar rats' reproductive organs, sperm production and testosterone level," Contraception, vol. 67, no. 4, pp. 327-331, 2003.

[7] R. M. S. Celeghini, J. H. Y. Vilegas, and F. M. Lanças, "Extraction and quantitative HPLC analysis of coumarin in hydroalcoholic extracts of Mikania glomerata Spreng. ("guaco") leaves," Journal of the Brazilian Chemical Society, vol. 12, no. 6, pp. 706-709, 2001.

[8] M. R. Ritter and J. L. Waechter, "Biogeografia do gênero Mikania Willd. (Asteraceae) no Rio Grande do Sul, Brasil," Acta Botânica Brasilica, vol. 18, no. 3, pp. 643-652, 2004.

[9] F. Oliveira, M. L. Saito, and L. O. Garcia, "Morfologia externa das partes aéreas e anatomia foliar das espécies brasileiras de Mikania Willdenow secção Globosae Robinson-visão farmacognóstica," Lecta-USF, vol. 12, no. 1, pp. 23-65, 1994.

[10] V. Lucas, "Estudo farmacognóstico do guaco Mikania glomerata Sprengel," Revista da Flora Medicinal, vol. 9, no. 3, pp. 101-132, 1942.

[11] E. S. Suyenaga, E. Reche, F. M. Farias, E. E. S. Schapoval, C. G. M. Chaves, and A. T. Henriques, "Antiinflammatory investigation of some species of Mikania," Phytotherapy Research, vol. 16, no. 6, pp. 519-523, 2002.

[12] A. E. Bighetti, M. A. Antônio, L. K. Kohn et al., "Antiulcerogenic activity of a crude hydroalcoholic extract and coumarin isolated from Mikania laevigata Schultz Bip," Phytomedicine, vol. 12, no. 1-2, pp. 72-77, 2005.

[13] S. C. Davino, A. M. Giesbrecht, and N. F. Roque, "Antimicrobial activity of kaurenoic acid derivatives substituted on carbon-15," 
Brazilian Journal of Medical and Biological Research, vol. 22, no. 9, pp. 1127-1129, 1989.

[14] R. Yatsuda, P. L. Rosalen, J. A. Cury et al., "Effects of Mikania genus plants on growth and cell adherence of mutans streptococci," Journal of Ethnopharmacology, vol. 97, no. 2, pp. 183-189, 2005.

[15] M. G. R. Leite, C. L. de Souza, M. A. M. da Silva, L. K. A. Moreira, A. F. J. de Matos, and G. S. B. Viana, "Pharmacological effects of Mikania glomerata Spreng (guaco), Justicia pectoralis Jacq (anador) and Torresea cearensis Fr. All (cumaru)," Revista Brasileira de Farmacia, vol. 74, no. 1, pp. 12-15, 1993.

[16] F. Oliveira, M. A. Alvarenga, G. Akisue, and M. K. Akisue, "Isolamento e identificação de componentes químicos de Mikania glomerata Sprengel e de Mikania laevigata Schultz Bip. ex Baker," Revista de Farmácia e Bioquímica da Universidade de São Paulo, vol. 20, no. 2, pp. 169-183, 1984.

[17] V. L. G. Rehder, A. Sartoratto, P. M. Magalhães et al., “Teor de cumarina em Mikania laevigata Schultz Bip. ex Baker em função do cultivo, colheita e secagem," in Anais do XV Simpósio de Plantas Medicinais do Brasil, Lindoia, Brazil, 1998.

[18] R. S. de Moura, S. S. Costa, J. M. Jansen et al., "Bronchodilator activity of Mikania glomerata Sprengel on human bronchi and guinea-pig trachea," Journal of Pharmacy and Pharmacology, vol. 54, no. 2, pp. 249-256, 2002.

[19] C. N. Lin, S. J. Liou, T. H. Lee, Y. C. Chuang, and S. J. Won, "Xanthone derivatives as potential anti-cancer drugs," Journal of Pharmacy and Pharmacology, vol. 48, no. 5, pp. 539-544, 1996.

[20] A. de Fátima, L. K. Kohn, M. A. Antônio et al., “( $R)$ goniothalamin: total syntheses and cytotoxic activity against cancer cell lines," Bioorganic and Medical Chemistry, vol. 13, no. 8, pp. 2927-2933, 2005.

[21] C. Graça, C. S. Freitas, C. H. Baggio, P. R. Dalsenter, and M. C. A. Marques, "Mikania laevigata syrup does not induce side effects on reproductive system of male Wistar rats," Journal of Ethnopharmacology, vol. 111, no. 1, pp. 29-32, 2007.

[22] M. J. Simmons and D. P. Snustad, Fundamentos de Genética, Guanabara Koogan, Rio de Janeiro, Brazil, 2nd edition, 2001.

[23] R. D. J. Costa, A. Diniz, M. S. Mantovani, and B. Q. Jordão, "In vitro study of mutagenic potential of Bidens pilosa Linné and Mikania glomerata Sprengel using the comet and micronucleus assays," Journal of Ethnopharmacology, vol. 118, no. 1, pp. 86-93, 2008.

[24] G. C. Yen and H. Y. Chen, "Relationship between antimutagenic activity and major components of various teas," Mutagenesis, vol. 11, no. 1, pp. 37-41, 1996.

[25] M. C. T. Duarte, G. M. Figueira, A. Sartoratto, V. L. G. Rehder, and C. Delarmelina, "Anti-Candida activity of Brazilian medicinal plants," Journal of Ethnopharmacology, vol. 97, no. 2, pp. 305-311, 2005.

[26] J. B. Harborne, "Phenolic compounds," in Phytochemical Methods: A Guide to Modern Techniques of Plant Analysis, J. B. Harborne, Ed., pp. 40-106, Chapman and Hall, London, UK, 3rd edition, 1998.

[27] H. Wagner and S. Bladt, Plant Drug Analysis: A Thin Layer Chromatography Atlas, Springer, Berlin, Germany, 2nd edition, 1996.

[28] BRASIL, Farmacopéia Brasileira, Parte II, vol. 4, Atheneu, São Paulo, Brazil, 4th edition, 2002.

[29] S. I. R. Franke, D. Prá, J. da Silva, B. Erdtmann, and J. A. P. Henriques, "Possible repair action of Vitamin C on DNA damage induced by methyl methanesulfonate, cyclophosphamide,
$\mathrm{FeSO}_{4}$ and $\mathrm{CuSO}_{4}$ in mouse blood cells in vivo," Mutation Research, vol. 583, no. 1, pp. 75-84, 2005.

[30] J. A. Nemzek, G. L. Bolgos, B. A. Williams, and D. G. Remick, "Differences in normal values for murine white blood cell counts and other hematological parameters based on sampling site," Inflammation Research, vol. 50, no. 10, pp. 523-527, 2001.

[31] N. P. Singh, M. T. McCoy, R. R. Tice, and E. L. Schneider, "A simple technique for quantitation of low levels of DNA damage in individual cells," Experimental Cell Research, vol. 175, no. 1, pp. 184-191, 1988.

[32] J. da Silva, T. R. O. de Freitas, J. R. Marinho, G. Speit, and B. Erdtmann, "An alkaline single-cell gel electrophoresis (comet) assay for environmental biomonitoring with native rodents," Genetics and Molecular Biology, vol. 23, no. 1, pp. 241-245, 2000.

[33] I. V. Villela, I. M. de Oliveira, J. da Silva, and J. A. P. Henriques, "DNA damage and repair in haemolymph cells of golden mussel (Limnoperna fortunei) exposed to environmental contaminants," Mutation Research, vol. 605, no. 1-2, pp. 78-86, 2006.

[34] M. Collins, M. Dusinska, M. Franklin et al., "Comet assay in human biomonitoring studies: reliability, validation and applications," Environmental and Molecular Mutagenesis, vol. 30, no. 2, pp. 139-146, 1997.

[35] M. A. Berhow, E. D. Wagner, S. F. Vaughn, and M. J. Plewa, "Characterization and antimutagenic activity of soybean saponins," Mutation Research, vol. 448, no. 1, pp. 11-22, 2000.

[36] H. Nishino, "Cancer prevention by carotenoids," Mutation Research, vol. 402, no. 1-2, pp. 159-163, 1998.

[37] D. Patel, S. Shukla, and S. Gupta, "Apigenin and cancer chemoprevention: progress, potential and promise (review)," International Journal of Oncology, vol. 30, no. 1, pp. 233-245, 2007.

[38] Y. J. Surh and L. R. Ferguson, "Dietary and medicinal antimutagens and anticarcinogens: molecular mechanisms and chemopreventive potential-highlights of a symposium," Mutation Research, vol. 523-524, pp. 1-8, 2003.

[39] J. B. F. Fernandes and V. M. F. Vargas, "Mutagenic and antimutagenic potential of the medicinal plants $M$. laevigata and $C$. xanthocarpa," Phytotherapy Research, vol. 17, no. 3, pp. 269-273, 2003.

[40] R. C. da Silveira e Sá, M. N. Leite, V. M. Peters, M. D. O. Guerra, and R. N. de Almeida, "Absence of mutagenic effect of Mikania glomerata hydroalcoholic extract on adult wistar rats in vivo," Brazilian Archives of Biology and Technology, vol. 49, no. 4, pp. 599-604, 2006.

[41] E. R. Martins and R. H. S. Santos, "Plantas medicinais: uma alternativa terapêutica de baixo custo," Viçosa Informe Técnico, Imprensa Universitária da Universidade Federal de Viçosa, vol. 16, no. 73, 34 pages, 1995.

[42] A. C. Osório and J. L. S. Martins, "Determinação de cumarina em extrato fluido e tintura de guaco por espectofotometria derivada de primeira ordem," Revista Brasileira de Ciências Farmacêuticas, vol. 40, no. 4, pp. 481-486, 2004.

[43] A. F. Costa, Farmacognosia, Fundação Calouste Gulbenkian, Lisboa, Portugal, 4th edition, 1994.

[44] E. Horvathova, D. Slamenova, L. Hlincikova et al., "The nature and origin of DNA single-strand breaks determined with the comet assay," Mutation Research, vol. 409, no. 3, pp. 163-171, 1998.

[45] S. Boiteux and M. Guillet, "Abasic sites in DNA: repair and biological consequences in Saccharomyces cerevisiae," DNA Repair, vol. 3, no. 1, pp. 1-12, 2004. 
[46] S. I. R. Franke, D. Prá, B. Erdtmann, J. A. P. Henriques, and J. da Silva, "Influence of orange juice over the genotoxicity induced by alkylating agents: an in vivo analysis," Mutagenesis, vol. 20, no. 4, pp. 279-283, 2005.

[47] S. T. Matalon, A. Ornoy, and M. Lishner, "Review of the potential effects of three commonly used antineoplastic and immunosuppressive drugs (cyclophosphamide, azathioprine, doxorubicin on the embryo and placenta)," Reproductive Toxicology, vol. 18, no. 2, pp. 219-230, 2004.

[48] M. Vrzoc and M. L. Petras, "Comparison of alkaline single cell gel(Comet) and peripheral blood micronucleus assays in detecting DNA damage caused by direct and indirect acting mutagens," Mutation Research, vol. 381, no. 1, pp. 31-40, 1997.

[49] R. R. Tice, E. Agurell, D. Anderson et al., "Single cell gel/comet assay: guidelines for in vitro and in vivo genetic toxicology testing," Environmental and Molecular Mutagenesis, vol. 35, no. 3, pp. 206-221, 2000. 

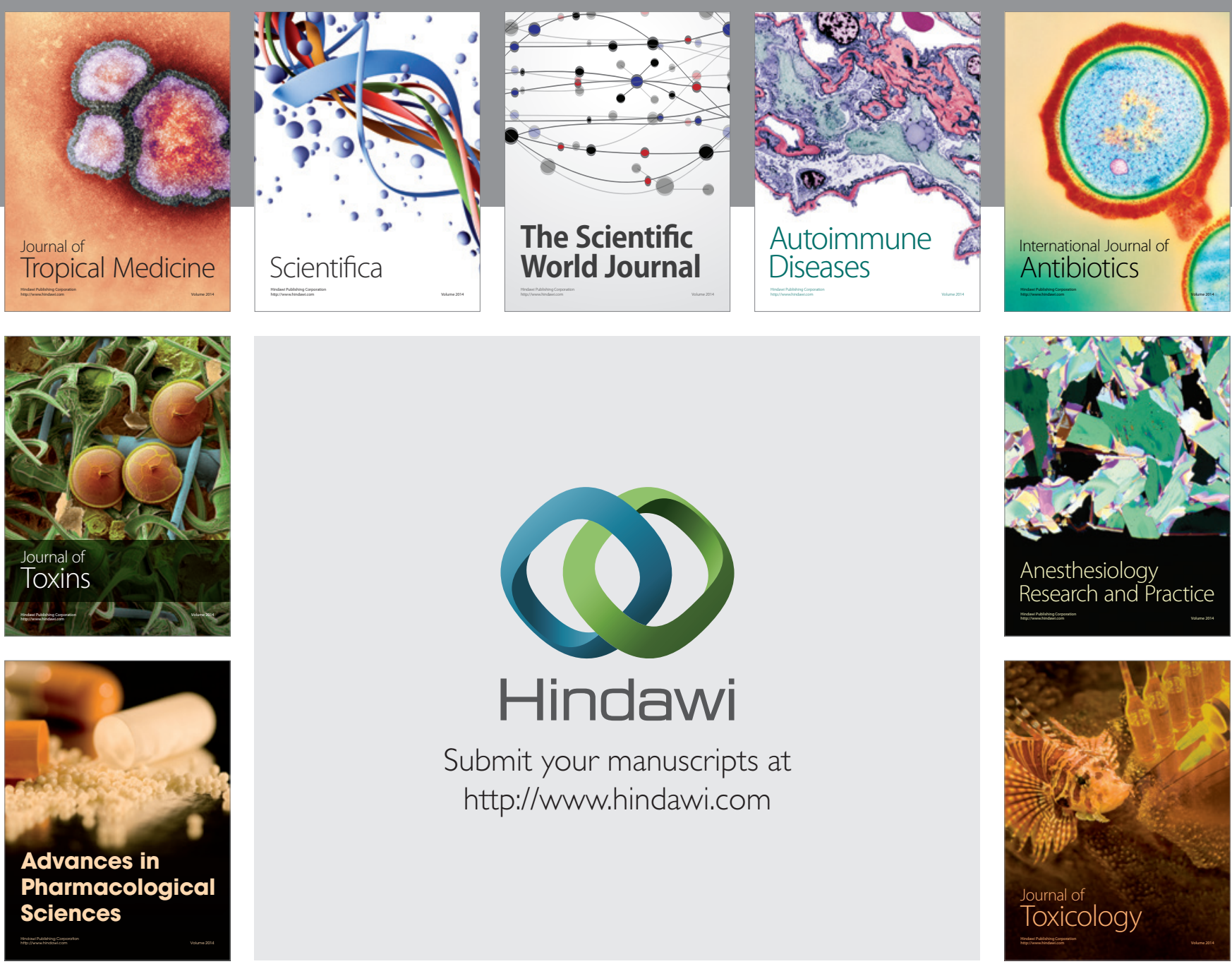

\section{Hindawi}

Submit your manuscripts at

http://www.hindawi.com
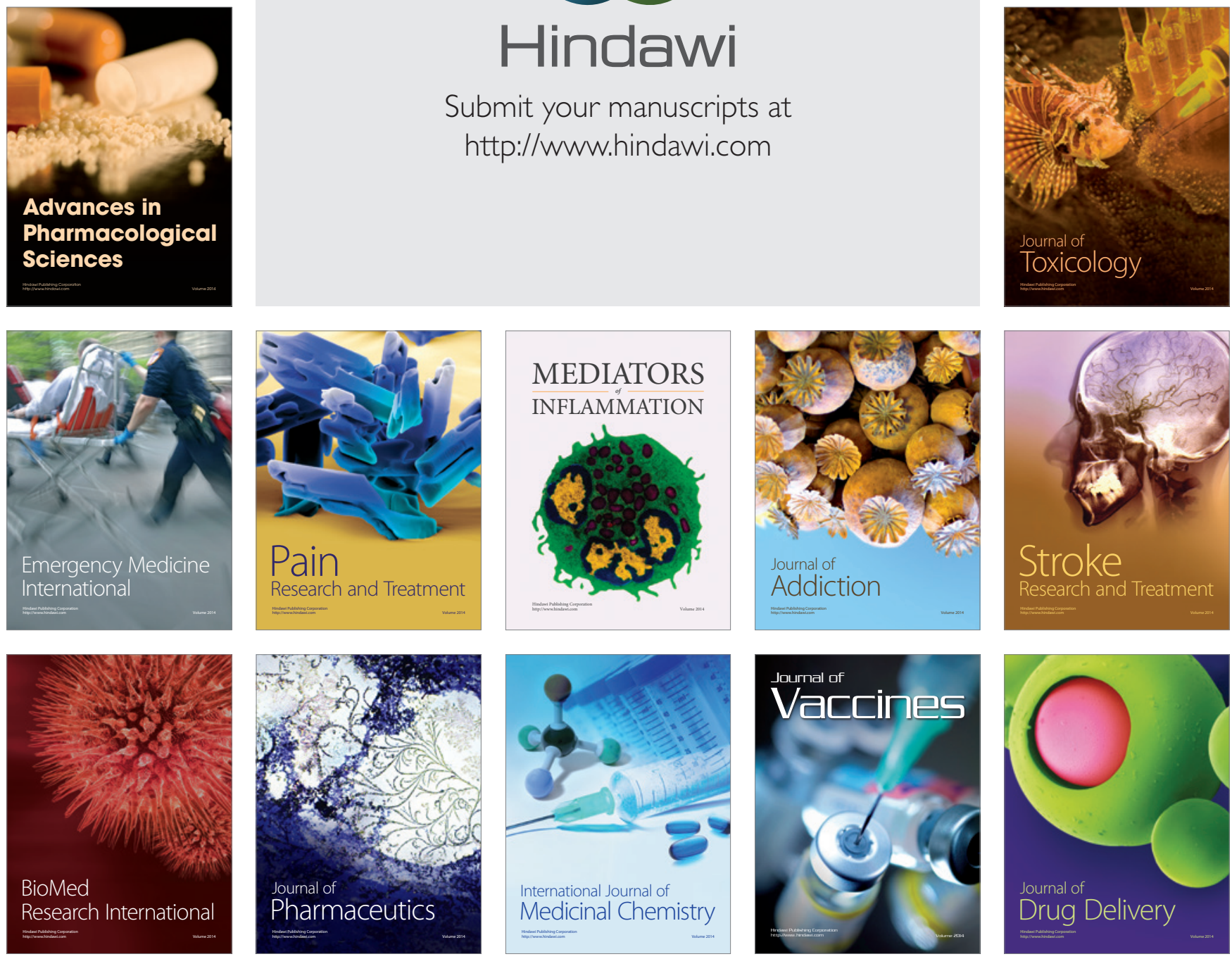